\title{
EXAMPLES REGARDING THE DIMENSION OF MARINE TRANSPORTATION AND OPERATION OF RUSSIAN SHIPS IN THE OTTOMAN WATERS ACCORDING TO OTTOMAN ARCHIVES (1860-1914)
}

\section{Fulya DÜVENCİ KARAKOÇ*}

\begin{abstract}
In the second half of the 19th century, Russia made its presence felt in economic and cultural areas in the Ottoman Middle East. For example, there were 70 Russian schools in Beirut and its vicinity. There were Russian representatives in Beirut Trade Court, too. Russian ships carried 45.112 tons of load from Beirut ports (1894).

Ships setting sail from Odessa sailed to the ports of Istanbul, Izmir, Thessaloniki, Chios, Rhodes, Sidon, Sur, Acre, Haifa, Jaffa, Tripoli, Beirut, Alexandria. After the opening of the Suez Canal (1869), we see that Russian ships passed to Persian Gulf and even Vladivostok (records dated 1884, 1893). The Russian ship running to Isle of Aynaroz (Thessaloniki) carried goods and passengers to the Russian monastery there. There were also Russian ships carrying Caucasian immigrants to the Eastern Mediterranean ports.

The Ottoman central administration and the Russian consuls in the Ottoman port cities monitored problems related to this marine transportation. Although political problems existed and even war periods were lived between the Ottoman State and the Russian Tsardom in this period, it is observed that ethical ruled were obeyed in marine transportation. In 1882, Vasil Bulkof, the captain of the Russian ship called Azof, was given a decoration "on the grounds that he helped an Ottoman ship having lost its way due to fog". Medals were given to "those rescuing the pilgrims from Bukhara in the Russian ship having come into collision with the Mecca ship in the Bosphorus between the Rumelian Fortress and the Anatolia

* Dr., Uludağ Üniversitesi, e-posta: fulyaduvenci@yahoo.com
\end{abstract}


Fortress” (1906). The Russian flagship drifting in Black Sea to the Ottoman shores was given food aid with the permission of the administration (1894). According to the list existing in the Ottoman archives, it is eye-catching that together with various food stuff, 9 barleys of beer, 24 big bottles of champagne and 80 bottles of Bordeaux wine were given to the mentioned ship.

In this study of ours, we will get benefited from Ottoman Provincial Salnames, Ottoman archive documents and relevant literature. We will try to clarify the ports which "Russian ships" stopped by, the amounts of cargo they carried and the dimensions of this marine transportation.

Key Words: Ottoman, Russian, Marine transportation, 19th century, Mediterranean.

\section{ÖZET}

\section{Rus Vapurlarının Osmanlı Sularında Denizciliğe Katkısına İlişkin Osmanlı Arşiv Örnekleri (1860-1915)}

19. Yüzyllın ikinci yarısında Rusya, Osmanlı Ortadoğusu'nda iktisadi ve kültürel alanlarda varlı gösteriyordu. Örneğin, Beyrut ve civarında 70 Rus okulu bulunuyordu. Beyrut Ticaret Mahkemesi'nde Rus temsilciler de vardl. Rus gemileri Beyrut limanlarından 45.112 ton yük taşımışlardl.(1894)

Odessa'dan denize açılan vapurlar İstanbul, Izmir, Selanik, Sakız, Rodos, Sayda, Sur, Akka, Hayfa, Yafa, Trablus, Beyrut, İskenderiye limanlarina sefer yapıyorlardl. Süveyş Kanalı'nın açılmasından sonra (1869) Rus vapurlarının Basra'ya hatta Vladivostok'a geçtiklerini görmekteyiz. (1884, 1893 tarihli kayıtlar) Aynaroz adasına (Selanik) işlemekte olan Rusya vapuru buradaki Rus manastırına eşya ve yolcu taşlyordu. Doğu Akdeniz limanlarına Kafkas göçmeni taşıyan Rus vapurlarl da vardl.

Osmanl merkezi yönetimi ve Osmanl liman kentlerinde bulunan Rus konsolosları bu deniz ulaşımına ilişsin sorunları izlemekteydiler. Bu dönemde Osmanlı Devleti ile Rus Çarlı̆̆ı arasında siyasal sorunlar olmasına, hatta savaş dönemleri yaşanmasına karşın, deniz taşımacılığında etik kurallara uyulduğu görülüyor. 1882 yılında "Azof adlı Rusya vapuru kaptanı Vasil Bulkof'a sisten yolunu şaşıran Osmanlı gemisine yardımcı olmasından dolayl” nişan verilmişti. "İstanbul boğazında Rumeli ve Anadolu hisarlarl arasında Mekke vapuru ile çarpışan Rusya vapurundaki Buhara hacılarını kurtaranlara" madalya verilmişti.(1906) Karadeniz'de Osmanl sahillerine sürüklenen Rus Amiral gemisine yönetimin izniyle gıda yardımı yapılmıştı.(1894) Osmanlı arşivindeki mevcut listeye göre çeşitli gıda malzemesi ile birlikte 9 Fıçı arpa suyu (bira), 24 büyük şişe şampanya ve 80 şişe Bordeux şarabı dikkati çeker.

$\mathrm{Bu}$ araştırmamızda Osmanl vilayet salnamelerinden ve Osmanlı arşivi belgelerinden ve ilgili literatürden yararlanacağız. "Rus vapurlarl”nın uğradığ limanları, taşıdıkları yük miktarını ve bu deniz taşımacıllğının boyutlarını aydınlatmaya çalışacă̆ı.

Anahtar Kelimeler: Osmanlı, Rus, Denizcilik, 19. Yüzyll, Akdeniz. 


\section{Appendix}

In 1764, James Watt invented condenser which was the first step toward steam engine and at 1782, he invented double acting rotary steam engine. Until 1787 new machines were used only for steam pumps and textile machines. In 1787, American inventor John Fitch launches a steamboat on Delaware River. This firt try was not economically succesfull. So in 1807 Robert Fulton's paddle steamer “Clermont” navigated on Hudson River and successed economically gain. The first steamboat in ocean was at 1809 but the first that finished the ocean trip was in 1819. That was also not a big step becouse most of the way sailed with canvases. After constructing the first practical steam locomotive at 1814, and inventing ship's screw propeller at 1827; marine technology devoleped very fastly. ${ }^{1}$

\section{Marine Network is up to: Laws, Port Management and City Development}

Following the 1774 Kucuk Kaynarca Treaty, Russia obtained the privilege to make free trade in the Black Sea, the Danube, and the Mediterranean. $^{2}$ Russian ships made passenger and merchandise transportation to all the ports in the Ottoman Seas from Trabzon to Beirut. After the opening of the Suez Canal (1869), they sailed even to the ports of Basra and Vladivostok in the Far East. Russia was the first state that had got this privilege. France and England wanted to have the some and gained this by the political clout at $19^{\text {th }}$ century. Anyway, there were European ships in the Ottoman Sea. In this context we should talk about consulates in Ottoman land. On the second half of $18^{\text {th }}$ century, trade, maritime and industrial development made all the states to improve consulate systems. Kucuk Kaynarca Treaty was also the beginning of Russian permanent representative in Istanbul and consulates in Balkans. The number of consulates were expanded very quickly on Ottoman land. This is very important because maritime which is the focus of this paper is connected with trade and mobility that are connected with law. Queue the reasons that make the ambiance propitious for maritime makes us to look at law system firstly. With this, consulate system that makes maritime easy to be used by traders

1 2

Bernard Grun, The Timetables of History, Simon\&Schuster, New York, 2005, s.303, 395.

QUATAERT Donald, Osmanlı Imparatorluğu 1700-1922, Çev. Ayşe Berktay, İletişim Yayınları, İstanbul, 2003; STRAYER Joseph, R-Hans W.Gatzke, The Mainstream of Civilication, Fourth ed., New York, 1984; JORGA Nicolae, Osmanl Imparatorluğu Tarihi, Çev. Nilüfer Epçeli, C.5, Yeditepe Yayınevi, İstanbul, 2005; İsmail Hakkı Uzunçarşı1l, Osmanlı Tarihi, C.IV/I, Ankara, 1995. 
also should be seen. After those, port management and city development that make respectively bureaucratic and physical environment suitable are very important.

The Ottoman order included not only the traditional law order but also the law of foreigners carried out by the consulates. Although this second institution was used mostly for foreigners and minorities, it was also an important basis for those who engaged in commerce in the Ottoman lands. ${ }^{3}$ About the consuls' great efforts in relation to legal disputes which their own citizens faced when engaging in commerce or staying in the Ottoman lands, there are many examples in Bursa French consulate registers. In the documents which we will examine, there will be examples related to the nature of the communication between the Russian consulates and the Ottoman units.

Port management is developed in the period under discussion. The quarantine practice at the Ottoman ports was a procedure concerning marine transportation. At the ports on the chain of Ottoman coast from Trabzon to Beirut, there were quarantine administrations. Moreover, Russian ships which carried passengers and merchandise were taken under quarantine. For example, a register dated 1894 includes the fact that ships carrying wheat, barley and gas would sail from Odessa to Istanbul after completing their quarantine durations. The fact that kerosene was carried from Odessa to Istanbul is an indication of the existence of a refinery in the Russian area. ${ }^{4} \mathrm{~A}$ separate tax was taken from ships which were applied the quarantine procedure. In the period under discussion, because of infectious diseases sometimes breaking out, the procedure of quarantine was applied. For example, it is understood that the bootlegged salt shipped from Russian coasts to the Black sea via Batum in 1893 posed a serious threat in infecting cholera. ${ }^{5}$ Again a register dated 1893 includes taking "all passengers to come from the Russian coasts to Sohum and to the border of the province of Trabzon under quarantine at the port of Kavak for ten days". ${ }^{6}$ Moreover, in a

3 Gülnihal Bozkurt, Gayrimüslim Osmanlı Vatandaşlarının Hukuki Durumu 1839-1914, Türk Tarih Kurumu Basımevi, Ankara, 1996; Uygur Kocabaşoğlu, Majestelerinin Konsolosları, İletişimYayınları, 2004.

1853 became a turning point with Polish Ignacy Lukasiewicz who used the petroleum gas lamb. After this date, the importance of petroleum has increased with every passing day. Moreover, in 1861, a businessman named Mirzoeff established the first petroleum refinery in Azerbaijan-Baku. Toward the end of the 19th century, with the invention of the engine running with petroleum, the importance of petroleum was doubled. 
register dated 1909, it is stated that "due to the illness of cholera breaking out in Russia, a quarantine cordon was established at the port of Trabzon against those who came from there". ${ }^{7}$ It were the Ministry of Health and the Ministry of Foreign Affairs that dealt with this matter.

City development is an important foot of this triangle that makes propitious ambiance for maritime. Because physical conditions of a port both in the sea and in the land, roads and railway lines corresponding with the port, accommodation choices in the city, the daily life properties for foreigners are all about city development.

\section{Beirut: As an example to see port management and city development in Ottoman Land}

And Beirut is a perfect example to see how a city developed for international trading especially because of maritime relations.

1894

\begin{tabular}{|r|r|r|r|r|r|l|}
\hline \multicolumn{3}{|c|}{ Yük (Ton) } & \multicolumn{3}{|c|}{ Sefer } & \\
\hline Toplam & Yelken & Vapur & Toplam & Yelken & Vapur & Taşıdığ Sancak \\
\hline 102725 & 45978 & 56247 & 2823 & 2750 & 73 & Devlet-i Aliyye-i Osmaniye \\
\hline 89558 & 0 & 89558 & 95 & 0 & 95 & Mısı \\
\hline 76457 & 0 & 76457 & 119 & 0 & 119 & Ingiltere \\
\hline 101449 & 0 & 101449 & 73 & 0 & 73 & Fransa \\
\hline 54113 & 877 & 53236 & 51 & 3 & 48 & Avusturya \\
\hline 45112 & 0 & 45112 & 33 & 0 & 33 & Rusya \\
\hline 12712 & 5706 & 006 & 27 & 12 & 11 & Italya \\
\hline 1057 & 0 & 1057 & 1 & 0 & 1 & Ispanyo1 \\
\hline 3980 & 0 & 3980 & 10 & 0 & 10 & Isvec Norvec \\
\hline 12894 & 9540 & 7354 & 50 & 36 & 14 & Yunan \\
\hline 504057 & 62101 & 441956 & 3282 & 2805 & 477 & Toplam \\
\hline
\end{tabular}

1899

\begin{tabular}{|c|c|c|c|c|c|c|}
\hline \multicolumn{3}{|c|}{ Sefer Saysis } & \multicolumn{3}{|c|}{ Yük (ton) } & \multirow[b]{2}{*}{ Sancak ve Bandira } \\
\hline Yekûn & Yelken Gemisi & Vapur & Yekûn & YelkenGemisi & Vapur & \\
\hline 142.937 & 58.281 & 57.656 & 2.739 & 2.562 & 177 & Osmanla \\
\hline 2.422 & & 2.422 & 2 & & 2 & Almanya \\
\hline 180.528 & & 180.528 & 230 & & 230 & Ingiliz \\
\hline 134.732 & & 134.733 & 94 & & 94 & Avusturya \\
\hline 22.461 & & 32.461 & 32 & & 32 & Misir \\
\hline 247.294 & & 247.294 & 132 & & 132 & Fransuz \\
\hline 15.116 & 9.208 & 5.908 & 55 & 29 & 26 & Yunan \\
\hline 13.455 & 2.306 & 11.049 & 23 & 9 & 24 & Italyan \\
\hline 742 & 742 & & 5 & 5 & & Sisam \\
\hline 77.798 & & 77.798 & 52 & & 53 & Rusya \\
\hline 1.359 & & 1.359 & 1 & & 1 & Norves \\
\hline 849.008 & & 75.120 & 3.370 & 2.609 & 761 & Yekûn \\
\hline
\end{tabular}


Beirut was the one of the big ports. At the end of $19^{\text {th }}$ century we can see Russian freight density on the tables. ${ }^{8}$ In 1894 the destiny was about 33 sailings and 45 thousand tons of shipment. In 1899 it became 53 sailings including 78 thousand tons of shipment. Russian was firstly sixth then fifth in the ordering. In Beirut example, we can see easily demographical and / or economical mobility. There were lots of sails to Beirut and nearer ports that were done by Russian ships not only for transporting shipment but also human. Trablusşam, Yafa, İskenderiye, Mersin were closer examples of ports near Beirut. We can see friday, saturday, sunday and monday Russian sails, means four times a week sailings from Beirut and these nearer ports also. In $19^{\text {th }}$ century Beirut Salnames, we can see the decreasing of mobility decidedly. Because of this decreasing; after 1899, the sails were written by sorting not type of the ships, but the days of the week. This result was the reason of another circle that represents more people could move and could trade and consequently relations were developed. Improvement was about not only social but also economical because of this circle. We can see the increasing of "Beirut Port Company Incomes" especially after 1898 in the chart, were the reasons of changes in the city. ${ }^{9}$

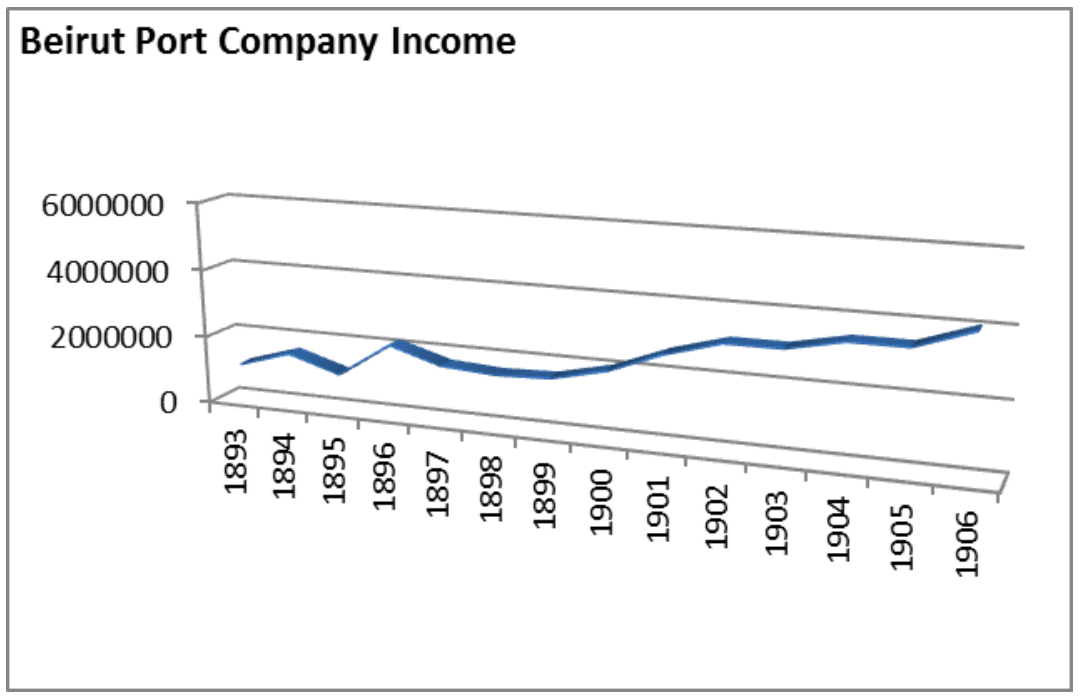

Fulya Düvenci Karakoç, Politics and Modernization in Damascus and Beirut (1860-1914) Uludag University Doctoral Thesis, 2011, p.141; Cf. Beirut Provincial Salname AESLN 230, p. 389; AESLN 231, p.126.

Düvenci Karakoç, a.g.t., p.290. 
In 1891, Vali of Beirut was İsmail Hakk1 Bey. The road between the the port and the city is enlarged by condemnation of the houses. This was an important step but not the only one. Development of railways between the inside areas and the sea was another. In 1890, the port extansion begun. There are too many photographs of these strenuous effort in the salnames.
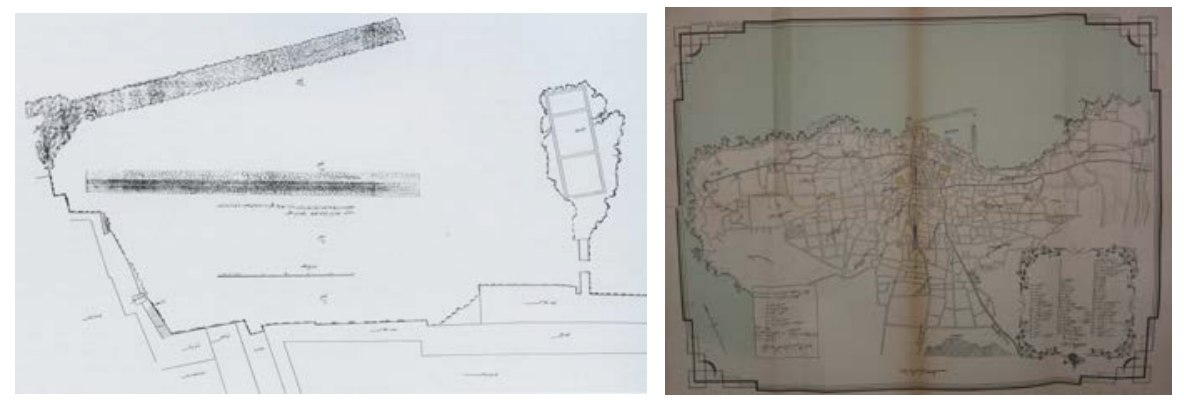

The plan of the port before extension shows the breakwater, locations of the offices authority of the quarantine and the customs, trade establishments, the residence of the port director, the customs pier, and the goods quay. Social and economic growth of the city made the provincial authorities do planning. This is an early city plan of Beirut that took place in the Salnames. These were the facts that improved the trade relations. But on the other hand, there were about 70 Russian schools in and around Beirut in those years. Moreover, there were Russian delegates in the Commercial Court of Beirut as well. So all the developments were interactive.

\section{Details About Russian Marine Network on the Ottoman}

\section{Sea}

There is a Russian monastery in the Isle of Ayranoz in the Aegean Sea across Thessaloniki. The "Russian Ferry" coming here regularly carry passengers to conduct religious ceremony. The Ottoman administration raises an objection to the ferry's docking the Isle of Ayranoz instead of the Port of Thessaloniki, which is its quarantine and customs order. According to 1861-dated Ottoman archive document, ferries carrying passengers and cargo to the Russian monastery, which was three hours away from the port of Ayranoz, were allowed to dock the port of Ayranoz instead of the port of Thessaloniki. Moreover, the Ottoman administration assign a physician, too. $^{10}$ 
When making investigations on ferries coming from Russia to the Ottoman ports in the years of 1883 and 1884, we also came across pieces of information about the navigation rules of the period, unexpected events and the Russian consulates. We learn that Vasil Bulkakof, the captain of Azor, one of the "Russian Company ferries running on the Trabzon line in 1883", helped an Ottoman ship. When the Russian ship sailing from Istanbul to Trabzon got the SOS signal from the ship named Sahin Bahri, which was under the captaincy of Halil Kaptan, it made a comeback from its route and pulled alongside of this ship. It was understood that the ship had lost its way and stayed in the middle of the sea for a few days, the crew and passengers had run out of food and drinks. Captain Vasil Burkakof made this Ottoman ship edge in with the shore by giving them some sea biscuits and water, which would be enough for them for a few days. ${ }^{11}$ Moreover, the Russian captain gave a report about this matter to the Russian consul in Trabzon. ${ }^{12}$

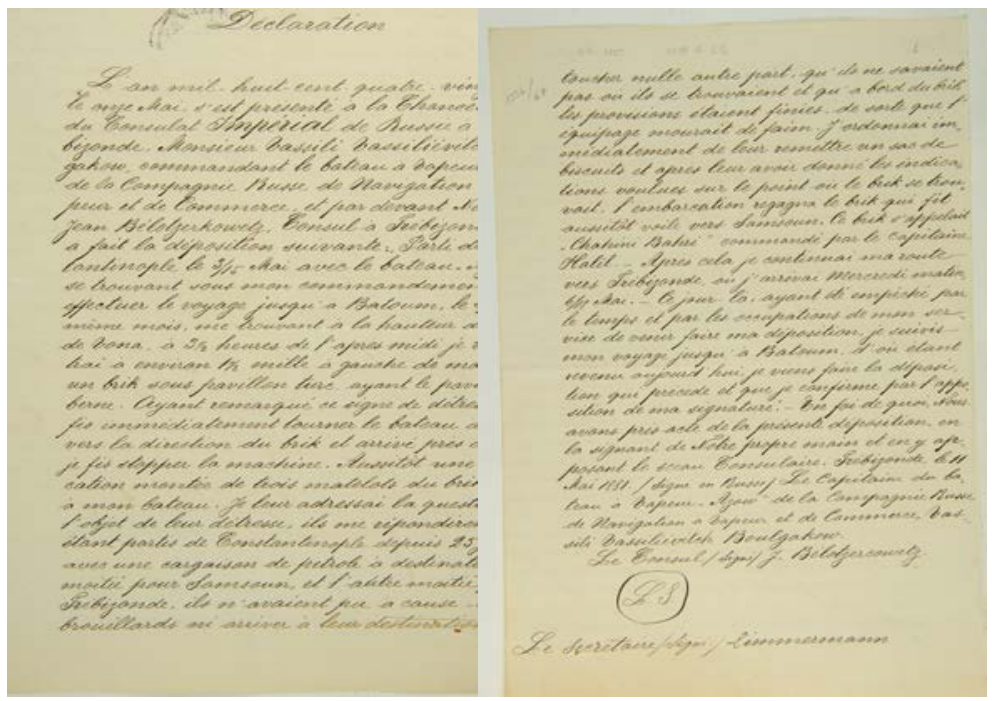

The Ottoman administration considered it appropriate to decorate the captain on the grounds that he spent time and consumed more coal and showed helpfulness by making a comeback from his route during this help. ${ }^{13}$ 


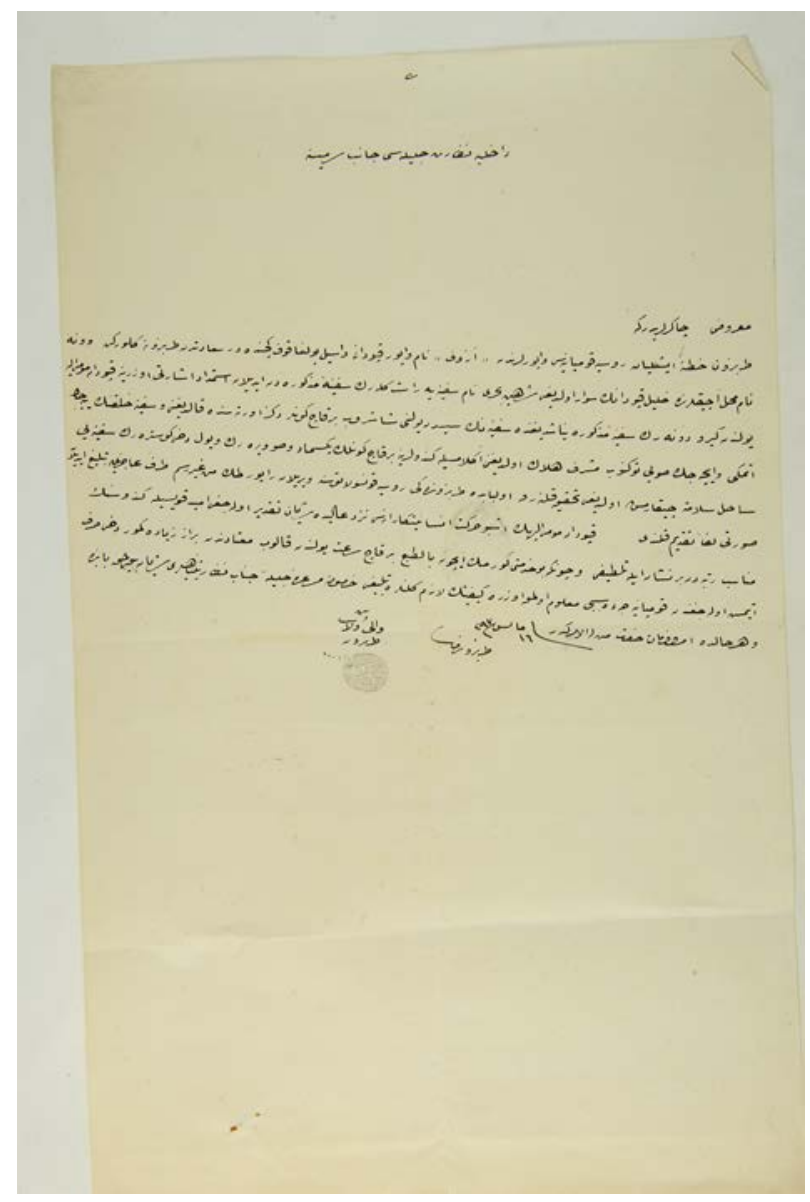

In Ottoman archive records, there is also information about marine accidents in which Russian ships were involved. For example, On April 10th 1867, "a Russian company ship" collided with a passenger ship belonging to the "Fevayede Osmaniye Company" in the Bosphorus. Of the passengers of the Kadikoy ferry, a person of French descent got injured and claimed a compensation. The matter was submitted to the Ottoman "Meclis-i Bahriye" (Maritime Affairs Council). However, on the day of the accident, the Russian ship sailed from Istanbul to Sevastopol. That the Russian ship was allowed to sail despite such an accident might have resulted from either the fact that the claim had not been submitted to the concerned port on that day or the fact that the Ottoman port administration did not function properly. The Ottoman administration wrote a letter to the Russian embassy and 
requested them to take necessary action to sit in judgment on the captains of the Russian and the Ottoman ships. ${ }^{14}$

In the Istanbul Strait in 1903, another marine accident happened. The Ottoman ship (Mecca Ship) carrying passengers in the strait collided with a Russian Ship between the Rumelian and the Anatolian fortresses. The Russian ship was carrying "Bukhara pilgrims". As it is known, Bukhara was in the area of Turkistan and nearer to Iran. However, it was probably more comfortable for pilgrims here to come to the coasts of the Black Sea or the Caspian Sea and go by ship to Alexandria after taking a journey on the Caspian Sea. The passengers of the Russian ship having an accident in the Strait were unshipped and put up by the Immigrant Management Office in Istanbul. The Ottoman Ministry of Internal Affairs granted 21 officials, who had showed effort about this matter, various awards. Among these were policemen and gendarmeries, port officials, boatmen and others concerned. The Ottoman administration took a close interest in the matter probably because it was pilgrims who were involved in the accident. ${ }^{15}$ In older records, we see that Russian ship carried Circassian immigrants coming from Caucasia as well. According to a register dated 1892, "the Circassian immigrants to come from Caucasia to Istanbul via the Russian ship were ordered to be unshipped without transshipping and sent to the place where they would be settled. ${ }^{16}$

An interesting register in our hand belongs to the period in which a war was going on between Russia and the Ottoman State. As it is known, in the period following the year of 1877, the wars resulted in heavy consequences in Caucasia and around the Danube River. We understand from a register belonging to the year of 1894 that despite such a negative political and military situation, humanistic aspects of shipping became prominent and a Russian ship was helped. A ship carrying a Russian Admiral, army officers and soldiers had a trouble in the Black Sea and the Ottoman state delivered "14 items of supply of provisions, etc." upon the personal approval of Padishah. From the relevant minute, we also understand that the Muslim Ottoman upper administration delivered such alcoholic drinks as beer, champagne and wine among these provisions as well. It was likely that the aid materials included in the following list were demanded by 
the Russian ship upon need. Moreover, this list also sheds light on the kinds of foods consumed in a war ship in the mentioned period. ${ }^{17}$

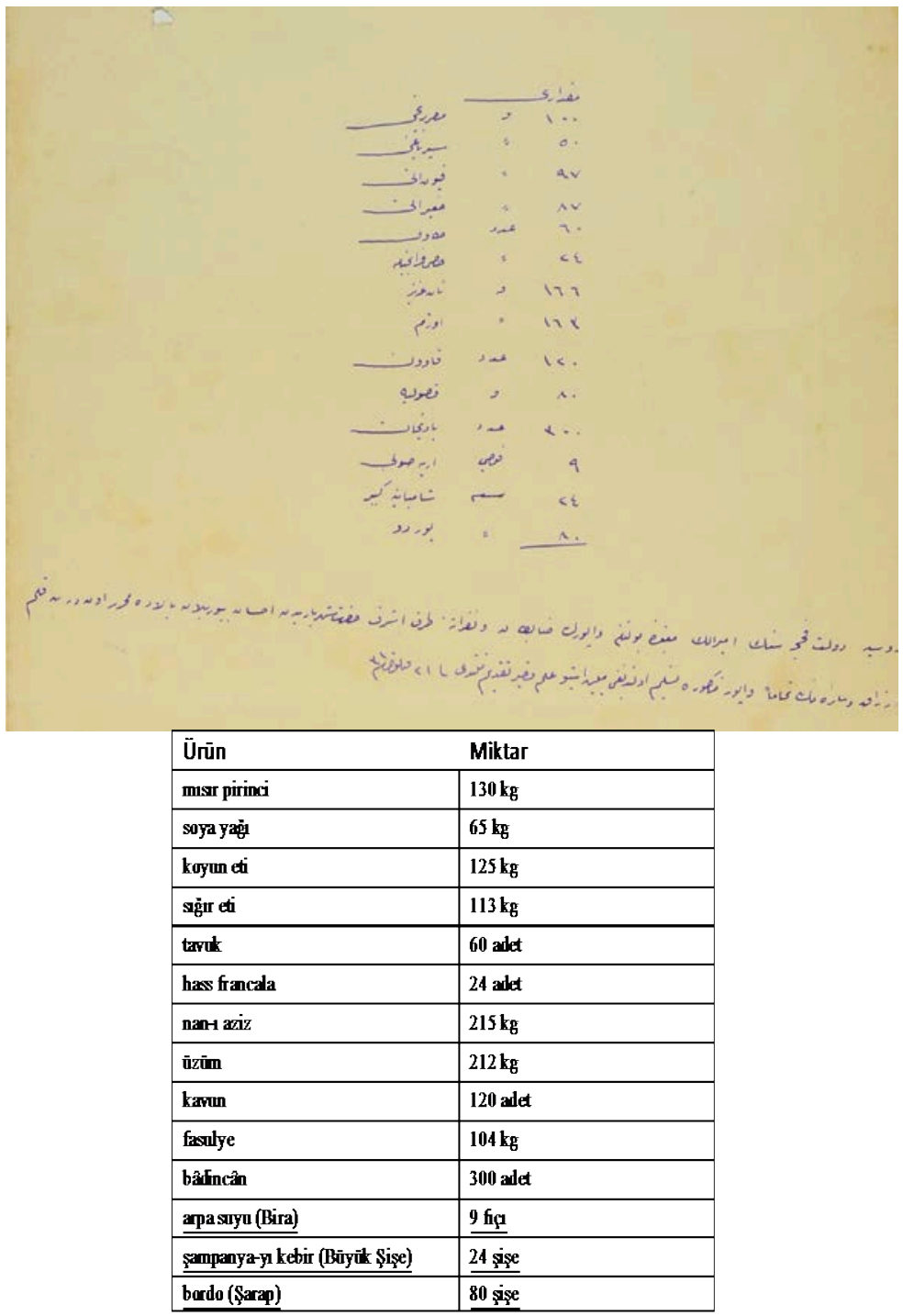

A register dated 1904 is related to an unfair practice applied to a "Russian ship coming to Chios". It is understood that extra money was demanded unfairly from Russian ships docking and unshipping merchandise 
at the Isle of Chios located in the Aegean Sea across Izmir in addition to wharfage and harborage. The Russian consul in Rhodes complained this situation to the Ottoman authorities. From the order sent by the Prime Ministry to the "Algeria Bahr-i Sefid Province" (Province of Mediterranean Islands), we understand that the Prime Ministry ordered the matter to be investigated and, if it appeared that they took extra taxes, it would be cancelled and attention be paid. ${ }^{18}$

An archive document dated 1883 does not only shed light on the Russian shipping organization in the mentioned period, but it also reveals the docking procedures applied to these ships at the Ottoman ports. According to the concerned record, in1883, the Russian State had post boats in the Baltic Sea. Of these, a "two-piece and sky- blue painted Russian ship with a tonnage of a thousand eight hundred which was under the captaincy of Kazay Kapudan” dropped anchor in front of Istanbul Harem port. The fact that the captain's name and such physical features as having a two-piece structure and being painted sky-blue were specified indicates a description which was valid in that period. The mentioned ship coming from Odessa docked Istanbul Harem port at 11.30 p.m. on March 5 1883, Saturday. It is understood that this post ship was running between Odessa and the Baltic Sea. The Ottoman governmental authorities made an inquiry into the docking ship and found out that it carried 800 male, female and children and it would sail to the Vladivostok port in Siberia at 6 a.m.. It is understood that the Russian ship would sail to the Mediterranean and pass through the Suez Canal and make a long journey. The Ottoman administration recorded that 800 passengers were migrating on their own wills. ${ }^{19}$

3 documents dated 1909 and found in the Ottoman prime ministry unit are related to a Russian ship broken into by some boatmen in the Beirut port. The passengers and the crew in the ship docking at the port got disturbed by the happening clash. "The attack claimed to have been done to the Russian ship" was complained by the Russian consul in Beirut to the Ottoman governmental authorities. It was likely that the boatmen acted like this in order to settle the dispute appearing as a result of the unshipping of passengers in favor of themselves. The governorship of Beirut, the Ottoman Ministry of Foreign Affairs and the Prime Ministry were informed about the matter. The authorities concerned were informed about the incident on the same day via a telegram. The Prime Ministry ordered the governorship of Beirut to have a talk with the consul immediately and state their sorry both 
in verbal and in written to the Russian consul appropriately. In the meantime, it is understood that the offensive boatmen were punished. ${ }^{20}$

\section{Conclusion}

Many examples showed that the ethical standarts of admiralty were very important. Cooperation, supporting, gratification and politeness are easily seen in all examples. They were more important than the military and competition.

\section{BIBLIOGRAPHY}

\section{Başbakanlık Osmanlı Arşivi (BOA)}

Babıâli Evrak Odası (BEO) 30/2215; 27/2002; 3206/240407; 2473/185450; 3215/ 241121; 3193/239432; 3180/238465

Bab-1 Asafi Mektubî Kalemi Mühimme Evrakı (A.MKT.MHM) 233/60 13602-3-4

Hariciye Nezareti Tercüme Odas1 (HR TO) 494/94

Dahiliye Nezareti Mektubî Kalemi (DH. MKT.) 924/1; 1775/12

Yıldız Perâkende Evrakı Hazine-i Hassa Maruzatı 28/16

Yıldız Perâkende Evrakı Askeri Maruzat 17/13

DÜVENCİ KARAKOÇ Fulya, Politics and Modernization in Damascus and Beirut (1860-1914), Uludag University Doctoral Thesis, 2011

GRUN Bernard, The Timetables of History, Simon\&Schuster, New York, 2005

JORGA Nicolae, Osmanlı Imparatorluğu Tarihi, Çev. Nilüfer Epçeli, C.5, Yeditepe Yayınevi, İstanbul, 2005

STRAYER Joseph, R-Hans W.Gatzke, The Mainstream of Civilication, Fourth ed., New York, 1984

UZUNÇARŞILI İsmail Hakkı, Osmanlı Tarihi, C.IV/I, Ankara, 1995 QUATAERT Donald, Osmanl Imparatorluğu 1700-1922, Çev. Ayşe Berktay, İletişim Yayınları, İstanbul, 2003 
